\title{
A New Approach for Investigating the Impact of Pesticides and Nutrient Flux from Agricultural Holdings and Land-Use Structures on Baltic Sea Coastal Waters
}

\author{
Lidia Dzierzbicka-Glowacka $^{1 *}$, Maciej Janecki ${ }^{1}$, Dawid Dybowski ${ }^{1}$, \\ Beata Szymczycha ${ }^{2}$, Hanna Obarska-Pempkowiak ${ }^{3}$, Ewa Wojciechowska ${ }^{3}$, \\ Piotr Zima $^{3}$, Stefan Pietrzak ${ }^{4}$, Grażyna Pazikowska-Sapota ${ }^{5}$, Beata Jaworska-Szulc ${ }^{3}$, \\ Artur Nowicki ${ }^{1}$, Żaneta Kłostowska², Adam Szymkiewicz ${ }^{3}$, \\ Katarzyna Galer-Tatarowicz ${ }^{5}$, Marcin Wichorowski ${ }^{6}$, Michał Białoskórski ${ }^{7}$, \\ Tadeusz Puszkarczuk ${ }^{8}$
}

${ }^{1}$ Institute of Oceanology, Polish Academy of Sciences, Physical Oceanography Department, Sopot, Poland ${ }^{2}$ Institute of Oceanology, Polish Academy of Sciences, Marine Chemistry and Biochemistry Department, Sopot, Poland ${ }^{3}$ Gdańsk University of Technology, Faculty of Civil and Environmental Engineering, Gdańsk, Poland ${ }^{4}$ Institute of Technology and Life Sciences, Department of Water Quality, Raszyn, Poland ${ }^{5}$ Maritime Institute in Gdansk, Department of Environment Protection, Gdańsk, Poland ${ }^{6}$ Institute of Oceanology PAS, IT Department, Sopot, Poland ${ }^{7}$ Academic Computer Centre in Gdansk, Gdańsk, Poland ${ }^{8}$ Municipality of Puck, Puck, Poland

Received: 6 March 2018

Accepted: 22 June 2018

\begin{abstract}
Knowledge related to land-use management impacts on the Baltic Sea ecosystem is limited. The constant release of pollutants into water bodies has resulted in water quality degradation. Therefore, only the innovative approaches integrated with research will provide accurate solutions and methods for proper environment management and will enable understanding and prediction of the impacts of land-use in the Baltic Sea region. Modelling approaches have become essential to address water issues and to evaluate ecosystem management. There are many water quality models, but only a few work in the operational mode and only some of them can be used as an interactive tool for environmental management to assess the impact of pollution on water quality. This study presents a new approach for investigating the influence of pesticides and nutrient fluxes from agricultural holdings and land-use
\end{abstract}

*e-mail: dzierzb@iopan.gda.pl 
structures on coastal waters of the Baltic Sea. Called WaterPUCK, this method will enable calculation of the sufficient amount of fertilizers, investigation nutrients, and pesticide sources and model: the fate and distribution of nutrients and pesticides in the surface water and groundwater; loads of pollution to surface water and groundwater; fluxes of nutrients via submarine groundwater discharge (SGD) to the Baltic Sea coastal environment; the processes and mechanisms influencing the persistence of nutrients in the environment; and predict the changes in land use and climate change influence on the Bay of Puck ecosystem.

Keywords: eutrophication, coastal management, pollution, modeling, Bay of Puck

\section{Introduction}

The Baltic Sea is an inland sea bordered by intensive agricultural areas of the surrounding developed industrial countries [1]. Its catchment area is fourfold larger than the sea itself [2]. Due to anthropogenic pressure and a positive water balance, the Baltic has become one of the most polluted seas in the world. The main pathways of chemical substance flux to the region are rivers, along with other sources such as atmospheric deposition, diffuse runoff from land, industrial waste, shipping accidents, and wastewater treatment plants [3]. Additionally, submarine groundwater discharge (SGD) has recently been recognized as an important chemical substance source to the sea [4-5].

Increased loads of nutrients cause different kinds of water deterioration, such as eutrophication, hypoxia, and anoxia [10]. Nutrients discharged to the Baltic Sea originate mainly from anthropogenic activities in the catchment area. Agriculture and managed forestry cause $60 \%$ of the waterborne nitrogen and $50 \%$ of the waterborne phosphorus inputs to the sea [11]. The Baltic Marine Environment Protection Commission-Helsinki Commission (HELCOM) recommended several actions to reduce nutrient flux to the Baltic that resulted in a regular decrease from the late 1980 s, but nutrient concentrations are still relatively high, and eutrophication remains one of the most serious threats to the Baltic [12]. The health of the Baltic ecosystem also suffers from increased concentrations of other pollutants, such as metals and organic compounds [13].

Although access to clean and drinkable water is a prerequisite for a healthy life, the constant release of pollutants into water bodies has resulted in water quality degradation. To limit this situation, water quality models are used as research tools. Several actions and projects have been developed to solve the environmental problems of the Baltic Sea (e.g., Reduction of Baltic Sea Nutrient Inputs and Cost Allocation within the Baltic Sea Catchment- RECOCA, BONUS+ project) and other areas worldwide. The development of integrated approaches such as monitoring measures and modelling have become important tools not only for understanding the processes taking place in both inland and marine ecosystems but also for evaluating the impact of various land-use and climate scenarios on water quantity and quality at the basin scale [14].

Surface water models, groundwater models, and Baltic Sea ecosystem models and operational environmental systems are briefly discussed below.

\section{Surface Water and Groundwater Models}

The division of hydrological models in Western literature, in which the applied mathematical dependences of processes within the catchment were assumed as the criterion for division. On this basis, three main groups of models have been distinguished [16]: parametric, statistical, and deterministic. Parametric models are based on the characteristics of a given basin or its part by means of numerical parameters. This group is considered historically the first type of model. It was initiated by the SWM model and its continuation of HSPF. So far, many hydrological models of this type have been created, i.e., HEC-1, STORM, CREAMS, ANSWERS, or SWRRBWQ [15]. There is also an extension of parametric models (models with distributed parameters), consisting of the representation of the basin as an area divided into elements of any shape and surface. The division may take place on the subbasins or by applying a homogeneous or heterogeneous network of polygons that divide the entire catchment.

The group of statistical models [15-16] is characterized by a completely different approach to hydrological modelling. The basic assumption of such a model is an unknown phenomena occurring in the catchment. The result of the model's operation is elaborated on the basis of historical data analysis. In the case of inflow-outflow transformation itself, data on precipitation and outflow from the basin are analyzed.

The latest group of hydrological models are deterministic models. They are based on physical phenomena occurring in the catchment. The output values are calculated based on the mathematical representation of these phenomena. In the case of such an approach, spatial catchments are divided into small areas for which physical phenomena occurring in these areas can be considered homogeneous. The division takes into account both the spatial distribution of atmospheric phenomena and the characteristics of the catchment with its shape and coverage. In addition, it does not require historical data to work properly. 
The accuracy of the model depends on the number of physical phenomena considered describing physical processes in catchments. Because not all phenomena have been known until now, new deterministic models are still emerging, taking into account the current state of knowledge in hydrology. We can distinguish following deterministic models: SWAT, WASP, MIKE SHE, PRMS, Xin'anjiang, WASH123D, MEDIFIS, BAYMOD, and CASC2D [15, 17-20].

Currently, the development of hydrological models is mainly aimed at increasing the number of tasks for which models are to be used. The developed models are based mainly on physical phenomena (deterministic). In addition, more and more emphasis is put on the automation of the process of obtaining input data for models (GIS techniques), of which the numerical terrain model is the most important.

In addition, there is a study made by Tuoyo Adu et al. [21] with a review of 10 non-point source models, namely: AGNPS, ANSWERS, CREAMS, SWRRB, HSPF, SWAT, EPD RIV1, DMA, CMBA, and MA, giving consideration to their nature, components, area of use, strengths, and limitations. This review indicated that hydrological processes and mechanisms involved in the movement of non-point source pollutants have not been completely developed in these models [21].

\section{Ecosystem Models of the Baltic Sea}

Due to emissions from the large population in the catchment area, eutrophication has become a large environmental problem in the Baltic Sea during recent decades. The increased nutrient concentrations cause increased biomass production and consequently increased sedimentation of organic matter and decreased oxygen concentrations driving the extension of hypoxic bottom areas. In marine ecosystems, coupled physicalbiochemical models are considered to be an important step toward understanding the functioning of the environment and predicting changes due to different stressors, such as pollution and climate change [1]. There are several coupled physical-biogeochemical Baltic Sea models working either in an operational mode or being used for long-term simulations of biogeochemical cycles.

The Baltic Sea long-term large-scale eutrophication model (BALTSEM) [22-23] is a time-dependent ecosystem model developed by BNI Sweden and available through the Nest Decision Support System. BALTSEM simulates seasonal ecosystem dynamics driven by all the major transport mechanisms and nutrient biogeochemical fluxes in the Baltic, which is presented as a chain of 13 highly vertically resolved but horizontally averaged water columns and underlying sediments. All the major aspects of the Baltic ecosystem, such as eutrophication, food web dynamics, fishery, susceptibility to pollutants, and biodiversity, as well as their responses to climate change, are both affected by and reflected in the nutrient biogeochemical cycles.
The ecological regional ocean model (ERGOM) [24] is a biogeochemical model developed at Leibniz Institute for Baltic Sea Research in Warnemuende, Germany. It incorporates the nitrogen and phosphorus cycle. Originally developed for the Baltic, the model is specifically strong in representing processes related to hypoxia and anoxia. However, due to the generality of the processes described, the model can be also used for other seas and is also used for modelling the biology of the Benguela upwelling system. ERGOM is free software and has users in several institutes and universities around the Baltic.

The Swedish coastal and ocean biogeochemical model coupled to the Rossby Centre ocean circulation model (RCO-SCOBI) [25-26] was developed by the Swedish meteorological and hydrological institute (SMHI) in Sweden. The model is used to study the influence of climate change and human activities on biological and chemical processes and the cycling of nutrients in the seas surrounding Sweden and to support decision makers for marine environmental conservation. The SCOBI model handles dynamics of nitrogen, oxygen, and phosphorus, including inorganic nutrients, nitrate, ammonia, phosphate, and particulate organic matter consisting of phytoplankton, detritus, and zooplankton.

The 3D coupled ecosystem model of the Baltic Sea (3D CEMBS) [27-28] originates from the community climate system model/community earth system model (CCSM/CESM) coupled global climate model but has been downscaled and adapted for the Baltic Sea domain and further developed at the Institute of Oceanology, Polish Academy of Sciences. It is a $\mathrm{z}$-level coordinates, general circulation ocean model that solves the 3-dimensional primitive equations for stratified fluid using the hydrostatic and Boussinesq approximations. 3D CEMBS is configured at approximately $2.3 \mathrm{~km}$ horizontal resolution $\left(1 / 48^{\circ}\right)$. Vertically the model grid has 21 irregular layers. Currently the model is used in an operational mode providing $48 \mathrm{hr}$ forecast of hydrodynamical and biogeochemical parameters (cembs.pl). Results from 3D CEMBS serve as a boundary condition for the EcoPuckBay model.

RCO and BALTSEM both have their open boundary in Kattegat, while ERGOM and 3D CEMBS have their boundary in the western Skagerrak. The ERGOM, RCO-SCOBI, BALTSEM, and 3D CEMBS models are similar in that they handle dynamics of nitrogen, oxygen, and phosphorus, including the inorganic nutrients, nitrate, ammonia, and phosphate (and also silicate in BALTSEM and 3D CEMBS and inorganic carbon in ERGOM), and particulate organic matter consisting of phytoplankton (autotrophs), dead organic matter (detritus), and zooplankton (heterotrophs). Primary production assimilates the inorganic nutrients by three functional groups of phytoplankton, diatoms, flagellates, and others, and cyanobacteria. Organic material may sink and accumulate in the model sediment 
as benthic nitrogen and phosphorus (and silicate in BALTSEM and 3D CEMBS).

In brief, the key differences between them can be described by:

- Differences in treatment of dead organic matter: one state-variable for each nutrient vs. a single variable with constant $\mathrm{N} / \mathrm{P}$ ratio.

- Differences in parameterizations of $\mathrm{P}$ sediment dynamics, in particular redox dependent $\mathrm{P}$ processes.

- Resuspension and sediment transport: mechanistic description (from waves and currents) vs. simple parameterization.

- Different vertical and horizontal resolution.

\section{Operational Systems}

According to the existing literature, many of the presented solutions have been applied to both the Baltic Sea catchment area and the Baltic Sea.

One of them is CRIS (cris.ietu.katowice.pl) an integrated information system to support water management in the river catchment developed in the Institute for Ecology of Industrial Areas (IETU) in Katowice. This model is able to identify the impact of anthropogenic factors such as: land use, water consumption, wastewater discharge, and atmospheric deposition of pollutants on the balance and quality of water in the catchment area, as well as determine the impact of changing weather conditions on circulation of water in the catchment.

Another worth mentioning is eutrophication.eu, developed by the Swedish national agency SMHI within the SWITCH-ON project. This interactive service is an analysis and scenario tool to visualize and calculate nutrient status in European water bodies and estimate the effects of remedial measures. The showcase application visualizes results from the E-HYPE water quality model, describes nutrient transport across Europe, and allows for on-the-fly evaluation of scenarios. Historic and/or real-time data are provided from E-HYPE to clients performing large-scale water quality assessments, or as input data to oceanographic models and other downstream services.

These products, however, are not as interdisciplinary and complexed as implemented WaterPuck service, covering only a selected part of the pollutant transportation routes or its concentration. WaterPuck, on the other hand, investigates transport of fertilizers (among others) from the moment they have been used on the farm, following its ground and surface water propagation until it reaches the open waters and further by using a coupled physical and biogeochemical model of the Bay of Puck.

\section{Integrated Service WaterPUCK}

Therefore, usage of the presented tools needs to be integrated and go beyond examining single issues, species, or ecosystem functions in isolation. In this

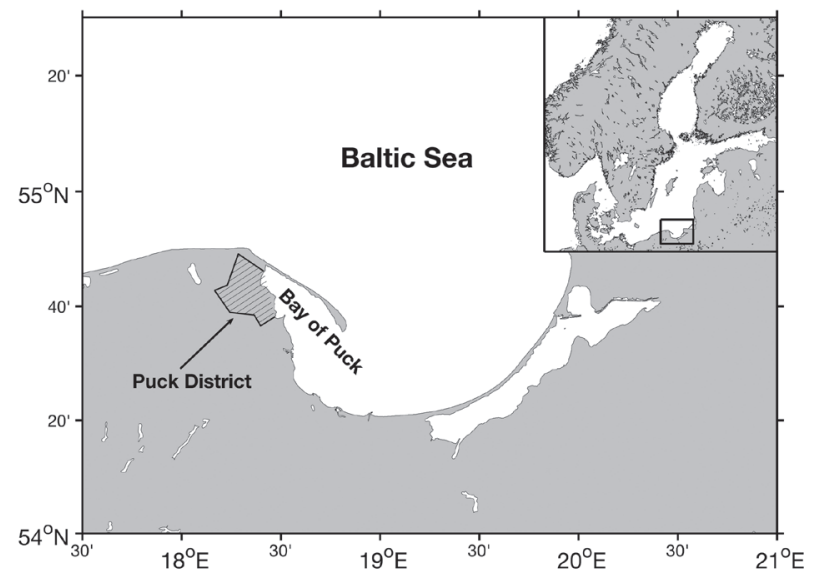

Fig. 1. Map of the study area: Puck District and the Bay of Puck.

study, we present a new approach, Service WaterPUCK, for investigating the impact of pesticides and nutrient flux from agricultural holdings and land-use structures on the coastal waters in a case study on the Bay of Puck in the Baltic Sea (Fig. 1), which will enable an understanding and prediction of the impacts of land use and climate change in the Baltic Sea region.

Our research seeks to develop a non-point source pollutant model that would not only adequately and effectively simulate non-point source pollutants in water bodies, but will also be easy to assess and be userfriendly and time-efficient.

\section{Research Area WaterPUCK}

The Puck District and the Bay of Puck are examples of a region where sustainable growth and management is a challenging task due to the region's complex structure [32]. The Bay of Puck is an inner basin of the Bay of Gdansk, which covers an area of approximately 40,000 ha. Its inner part is a shallow (average depth of $3 \mathrm{~m}$ ), sandy sea grass bed, while the outer part's average depth is $20.5 \mathrm{~m}$. The Bay of Puck's salinity ranges from 3 to 7 and is known as a nursery ground and breeding area for a number of fish and bird species. The bay contains several types of habitats (from muddy to stony bottom) located at a variety of shore types (i.e., sandy beaches, gravel beds, stony outcrops, clay cliffs, vegetated river mouths, etc.). The Bay of Puck is protected as a Natura 2000 site under both the birds and habitats directives. It is also a designated Baltic Sea Protected Area, and its inner waters are part of the Coastal Landscape Park [30]. The area has also been subjected to strong anthropogenic pressure. The main sources of pollution for the Bay of Puck are rivers [29], SGD [5], atmospheric deposition, and point sources, while the coastal ecosystem controls the biogeochemical transformations of $\mathrm{P}$ and $\mathrm{N}$ compounds (e.g., phosphate, nitrate, dissolved organic nitrogen, etc.) through close coupling between water and sediments [29]. 
Puck District is one of the largest municipalities in the Pomeranian Voivodeship, situated in the northern part of Poland at the southern coast of the southern Baltic Sea. The district has numerous rivers and springs, such as Płutnica, Reda, Czarna Wda, Gizdepka, and Błądzikowski channel. The district is mainly an agricultural area; however, dynamically growing tourism (mainly due to water sports and beautiful beaches) and the agritourism sector have started to play an important role in the area. Therefore, the main source of the inhabitants' incomes comes from agriculture, fishing, and tourism. The strategic actions and policy of the authorities of the district involve sustainable growth of the area; improving both the economy and the environment; respecting Natura 2000 legislation; and realizing international commitment to the European Union and European legislation, including the Water Framework Directive, the Marine Strategy Framework Directive, the Habitats Directive and the Baltic Sea Action Plan.

\section{Description of WaterPUCK Service}

The proposed approach, called WaterPUCK, is an innovative and complex method that enables researchers to identify the sources of nutrient and pesticide pollution, understand the main mechanisms responsible for the transport of these pollutants in surface and groundwater, calculate their flux via rivers and SGD, and directly assess the influence of pesticides and nutrient flux on the Bay of Puck ecosystem, including the creation of scenarios projecting the effects of changes in land use on chemical loads from the Puck District that are transported via surface and groundwater to the Bay of Puck.

WaterPUCK will combine several different components - such as data collection, determining environmental pressure indicators, retrospective analyses of existing monitoring data sets, in situ measures, and the application of various models - to estimate the main mechanisms and threats responsible for the transport of pollutants from the agricultural holdings and land-use structures to the surface and groundwater. WaterPUCK also has the potential to predict environmental changes in the district and the bay ecosystem.

WaterPUCK will integrate several models (Fig. 2), such as a surface water model based on SWAT [14, 31-36], a groundwater flow model based on MODFLOW [37], a 3D-ecohydrodynamic model of the Bay of Puck called EcoPuckBay based on the POP code [27-28, 3839], and an agriculture calculator called CalcGosPuck [40]. WaterPUCK will include several capabilities described in the following sections.

\section{Collecting Environmental Samples and Data}

WaterPUCK will determine environment pressure indicators - in particular on surface and groundwater from nearby farms situated in the district - in relation to dispersed (i.e., lost in the process of agricultural production) loads of nitrogen, phosphorus, and pesticides. It will also perform environmental sampling for analyzing particulate and dissolved nutrients; pesticides; temperature; potential redox; $\mathrm{pH}$; and concentrations of dissolved inorganic carbon, DOC, $\mathrm{Mn}, \mathrm{Ca}, \mathrm{Mg}$, and $\mathrm{Na}$ in high resolution in respect

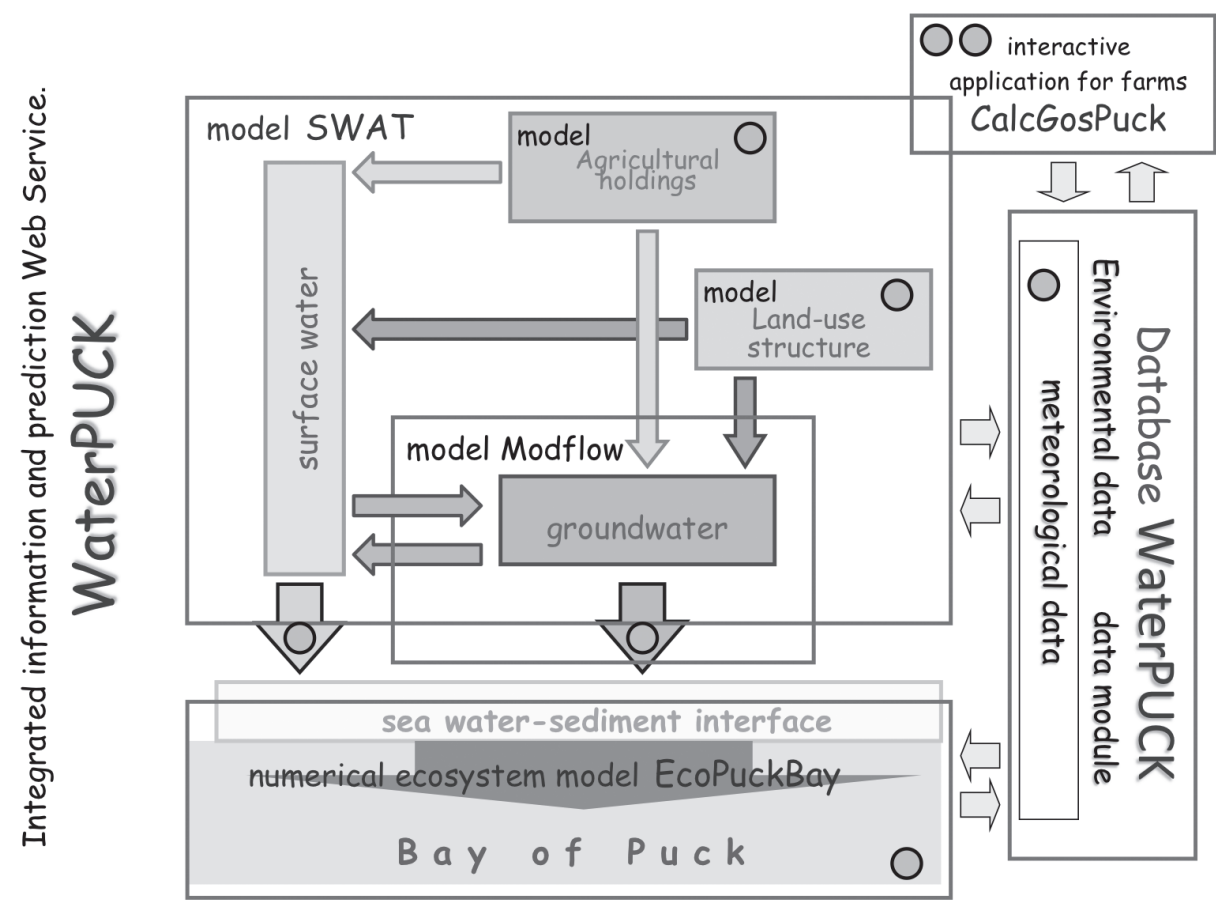

Fig. 2. The scheme of water and contaminant fluxes covered in WaterPUCK. 
to land use and cover. Denitrification in soils, groundwater, and SGD-impacted sites will be measured by means of membrane inlet mass spectrometry, which is the best method currently available [41].

\section{Surface Water Modelling}

Surface water modelling will include the preparation of an innovative and complex hydrological model, including meteorological data such as precipitation, wind, temperature, and atmospheric pressure. The proposed solution will be based upon real-time observation (i.e., a local weather station) and also on short-term weather forecasts. The hydrological computations are performed with the SWAT software. The transformation of precipitation data into surface runoff will be achieved with the Soil Conservation Service (SCS) curve number $(\mathrm{CN})$ procedure through the accumulated runoff volume and the time of concentration, or the time from the beginning of a rainfall event until the entire sub-basin area is contributing to flow at the outlet. Therefore, all data on land use and land cover will be analyzed. The cycle and transportation of nutrients and pesticides will be modelled using the SWAT. The SWAT covers sedimentation in surface and groundwater, and it also includes snow cover in the transportation model. Additionally, nutrient and pesticide transport will be taken into account. Finally, water quality parameters will be computed, including the amount of algae, dissolved oxygen, and carbonaceous biological oxygen demand entering the main channel with surface runoff. The whole chemical model will be bound with the observations and forecasts. The nutrient and pesticide migration step will be based on SWAT software, which will model the complete nutrient cycle for nitrogen (i.e., nitrification and denitrification, atmospheric deposition, fixation, leaching), phosphorus (i.e., mineralisation and decomposition) and carbon as well as the washoff and degradation of any pesticides applied in hydrologic response units. This requires identification and verification. The transformation of precipitation data into surface runoff is achieved with the SCS CN procedure based on the accumulated runoff volume and the time of concentration.

\section{Groundwater Modelling}

Groundwater modelling will be based on MODFLOW, which is the most widely used code for simulating groundwater flow and has been validated in hundreds of applications in many countries, including Poland. PHT3D is one of the most versatile packages for simulating the transportation of dissolved substances undergoing chemical reactions. Groundwater modelling will include an analysis of the available geological and hydrogeological data, the development of a conceptual scheme of groundwater circulation, the elaboration and calibration of a numerical model using MODFLOW code, the acquisition of data on nutrient and pesticide concentrations in groundwater, and the elaboration and calibration of a numerical model of contaminant transport using PHT3D code.

\section{Submarine Groundwater Discharge and Associated Chemical Flux Assessment}

The best available approach based on in situ measurements of chemical concentrations and flux and extrapolations for the study area will be used. Usually, information regarding the magnitude, chemical species composition, and stoichiometry of nutrient loads to marine environments is largely based on nutrient concentrations measured in surface water discharge sites, in groundwater collected from monitoring, and in water supply wells distributed throughout the watersheds. However, such an approach does not address the substantial biogeochemical complexity within the system. A fundamental problem with using well sampling to estimate chemical flux to estuaries is that the groundwater chemistry measured at some distance from bays is unlikely to be representative of the groundwater at the time that it discharges to the estuary. Biogeochemical processes in the aquifer and in the seepage zone can profoundly alter the loads of substances to the coastal aquifer; therefore, intense SGD measurements will be made within the project proposal in order to obtain the representative chemical substances flux. The obtained results will be included in the EcoBayPuck model.

\section{CalcGosPuck Establishment}

The calculator will be working as an independent application to calculate the discharge of pollution from agricultural holdings to the surface and groundwater, but it can also serve to calculate the nutrient distribution at the agriculture areas and estimate the processes that impact the productiveness of fertilizer usage at different sites. Generally, designated research indicators of pressures farms on water quality will be obtained, such as livestock density; consumption of nitrogen fertilizers; consumption of phosphate fertilizers; arable land and orchard consumption of plant-protection active substances; nitrogen and phosphorus surplus; concentrations of total nitrogen, total phosphorus, nitrogen nitrate, phosphorus phosphate, and pesticides in the water; and concentrations of pesticides in soil. CalcGosPuck will help to improve and plan fertilizer usage by farmers in order to obtain the best harvest policy and raise awareness.

\section{Developing the EcoPuckBay Model}

EcoPuckBay will be a three-dimensional ecohydrodynamic model of high vertical and horizontal resolution that assimilates in situ data measurements and takes into account the time/space variation of pesticide concentrations. EcoPuckBay will determine the 
spatiotemporal changes in the quality of marine waters in respect to specific pollution indicators. EcoPuckBay will be based on the POP code and will consist of hydrodynamic, biochemical, and pesticide modules. It will be a z-type model, meaning that the thickness of each layer will be identical for every cell and will be driven by the meteorological data. It will also be able to assimilate data from measurements. At the seashore, data from SGD measurements will be used as boundary conditions along with the river discharge data. From the side of the open sea, boundary conditions will be fed from the 3D CEMBS model. The hydrological part of the model will describe the behaviour of a stratified basin by solving spatial derivatives in the spherical coordinates using the finite element method. It will be able to solve momentum, continuity, and hydrostatic equations; equations of state; and tracer transport equations.

It will be responsible for calculating parameters such as water temperature, salinity, and currents. The biochemical model will consist of a set of variables such as nutrients, phytoplankton, zooplankton, dissolved oxygen, and organic matter. Each of these variables will be calculated with a second-order advection-diffusion, partial differential equation. The presented equation (1) describes the rate of change in the concentration of the variables in time and space, taking the source and loss functions into account:

$$
\frac{\partial S}{\partial t}+\left(V+w_{s}\right) \nabla S=\frac{\partial}{\partial z}\left(K_{z} \frac{\partial S}{\partial z}\right)+\sum_{i=1}^{2} \frac{\partial}{\partial x_{i}}\left(K_{x_{i}} \frac{\partial S}{\partial x_{i}}\right)+F_{S}
$$

... where $\mathrm{S}$ is each model variable, $\mathrm{V}(\mathrm{u}, \mathrm{v}, \mathrm{w})$ is the velocity vector, ws is the sinking velocity of pelagic detritus, $K_{z}$ and $K_{x i}$ are vertical and horizontal turbulent diffusion coefficients, and $F_{S}$ is the biogeochemical source-sink term. $F_{S}$ describes possible sources and losses of the diffusing substance in the space being studied, which is determined from knowledge of biogeochemical processes occurring in the marine environment and their mutual relations. The change in pesticide concentration will be calculated based on a similar equation. The pesticides are mainly introduced to the environment by being discharged from rivers and groundwater, and they are subjected to the process of sedimentation and bioaccumulation.

\section{WaterPUCK Service Development}

WaterPUCK will merge all models and result in an integrated innovative tool that enables simulations and the creation of scenarios and projects the effects of changes in land use on the loads of chemicals being transported through surface and groundwaters to the Bay of Puck.

The creation of the WaterPUCK Service structure will be based on two main tasks:
1) Development of an information system for the WaterPuck project, including development of system requirement specifications, system design (data model, ETL tools, data management tools, data extraction tools), IT infrastructure, and information system management

2) Development of a interactive, online information service for the municipality of Puck by designing a computer system hosting the WaterPuck service, which is necessary to clearly assess the impact of farms on the conditions of the study area (i.e., the commune of Puck), and data will originate from monitoring activities of project partners, data archives, publications, publicly available data, and the results of numerical model runs. All data have to be collocated with digital elevation and digital terrain models of the region.

\section{Discussion}

There are several possibilities of using operating systems that assess the impact of pollutants on water quality in order to increase and develop the R\&D sector and stimulate the private sector in research activities:

- Providing knowledge about sustainable usage of water resources by modeling the surface water and groundwater percolation (and using it for future predictions) and taking into account climate change (e.g., precipitation change).

- Help in understanding the ecosystem and sustainable management of surface water, groundwater, and land use.

- Environmental protection agencies can also use these tools to address the pollution source that will result in a more efficient monitoring system.

- Developing the numerical methods controlling the environmental status of the surface water, groundwater, and seawater enables for effective environment management and raising of novel and innovative practical solutions in Europe and rest of the World.

Implementing WaterPUCK Service will:

- Help local governments decide where certain investments should be located or whether the permission or license for the investment should be given.

- Significantly improve the management of natural resources and reduce losses resulting from declining revenues; developed solutions can be applied in other municipalities and coastal regions along the entire coastline of the Baltic Sea.

- Recognize the multiple functions of agroecosystems and many services they provide in order to foster an integrated approach to natural resource management, agricultural production, and food security.

- Help to predict seawater status knowing nutrient inflow to the Bay of Puck (a key Polish tourist region); therefore, tourists could plan their holidays 
according to the model predictions, knowing when and where harmful blooms will occur.

Currently Poland is considered one of the greatest pollution makers within the Baltic Sea countries. Therefore WaterPUCK can be used by Poland to implement reporting obligations required by the European Commission, HELCOM, and the European Environment Agency to update actual knowledge.

\section{Conclusions}

The proposed solution is an innovative product on the Polish and European market. Therefore, it will increase Polish products competiveness on an international scale, improve investment conditions, and most importantly give local governments a solution for maintaining good environmental status.

The proposed service is focused on determining the current and future environmental status of the surface water and groundwater located in the Puck District and its impact on the Bay of Puck environment.

One of the great advantages of modeling is a possibility to get results quickly. It also gives us a chance to test different scenarios without its real implementation, and the cost of research is much smaller than field measurements and it allows making analysis for the future concerning specific conditions. Of course in using the results of the model there is a need to remember that this is only an imperfect representation of complex processes taking place in reality and not reality itself [42].

To understand and manage the specific catchment area there is a need for interdisciplinary studies merging several scientific, economic, and social specializations. Hence, in order to develop the WaterPUCK concept successfully the best available scientific information and cooperation between research unit and external entities has been gathered. The Institute of Oceanology of the Polish Academy of Sciences in Sopot, the Technological University of Gdansk, the Maritime Institute in Gdansk, and the Institute of Technology and life Sciences in Falenty will exchange knowledge and good practices in order to provide tools for the Puck District that will enable it to improve the surface, ground, and seawater conditions for recent users such as farmers, fishermen, tourists, and future society. Thanks to such cooperation, monitoring and forecasting the state of the quality of surface and ground waters will improve and will be more precise and effective.

\section{Acknowledgements}

This work was supported by the National Centre for Research and Development within the BIOSTRATEG III program (No. BIOSTRATEG3/343927/3/ NCBR/2017) and research project No. UMO-2016/21/B/ ST10/0121 sponsored by the National Science Centre.
This is the first paper in the WaterPUCK project. It presents the structure of the WaterPUCK Service, which applies to the impact of pesticides and nutrient flux from agricultural holdings and land-use structures on the coastal waters of the Baltic Sea.

\section{Conflict of Interest}

The authors declare no conflict of interest.

\section{References}

1. NEUMANN T. Towards a 3D-ecosystem model of the Baltic Sea. J. Mar. Sys., 25, 405, 2000.

2. EMELYANOV E. Baltic Sea: geology, geochemistry, paleoceanography, pollution. Shishov Inst. Oceanol. Russ. Acad. Sci., Kaliningrad, Russia, 1995.

3. LEHTONEN K.K., BIGNERT A., BRADSHAW C., BROEG K., SCHIEDEK D. Chemical Pollution and ecotoxicology. Biol. Oceanog. Balt. Sea. Springer, Dordrecht, 547, 2017.

4. BURNETT W.C., AGGARWAL P.K., AURELI A., BOKUNIEWICZ H., CABLE J.E., CHARETTE M.A., KONTAR E., KRUPA S., KULKARNI K.M., LOVELESS A., MOORE W.S., OBERDORFER J.A., OLIVEIRA J., OZYURT N., POVINEC P., PRIVITERA A.M.G., RAJAR R.AMESSUR R.T., SCHOLTEN J., STIEGLITZ T., TANIGUCHI M., TURNER J. V. Quantifying submarine groundwater discharge in the coastal zone via multiple methods. Sci. Total Environ. 367 (2-3), 498, 2006.

5. SZYMCZYCHA B., VOGLER S., PEMPKOWIAK J. Nutrient fluxes via submarine groundwater discharge to the Bay of Puck, southern Baltic Sea. Sci. Total Environ. 438, 86, 2012.

6. SZYMCZYCHA B., MACIEJEWSKA A., WINOGRADOW A., PEMPKOWIAK J. Could submarine groundwater discharge be a significant carbon source to the southern Baltic Sea? Oceanologia 56 (2), 327, 2014.

7. SZYMCZYCHA B., PEMPKOWIAK J. The Role of Submarine Groundwater Discharge as Material Source to the Baltic Sea. GeoPlanet: Earth Planet. Sci. Book Ser., Springer, 2015.

8. SZYMCZYCHA B., KROEGER K.D., PEMPKOWIAK J. Significance of groundwater discharge along the coast of Poland as a source of dissolved metals to the southern Baltic Sea. Mar. Pollut. Bull. 109, 151, 2016.

9. DONIS D., JANSSEN F., LIU B., WENZHÖFER F., DELLWIG O., ESCHER P., SPITZY A., BÖTTCHER M. E. Biogeochemical impact of submarine groundwater discharge on coastal surface sands of the southern Baltic Sea. Estuar., Coast. Shelf Sci. 189, 131, 2017.

10. CONLEY D.J., CARSTENSEN J., AIGARS J., AXE P., BONSDORFF E., EREMINA T., HAAHTI B.M., HUMBORG C., JONSSON P., KOTTA J., LÄNNEGREN C., LARSSON U., MAXIMOV A., MEDINA M.R., ŁYSIAK-PASTUSZAK E., REMEIKAITĖ-NIKIENÈ N., WALVE J., WILHELMS S., ZILLÈN L. Hypoxia is increasing in the coastal zone of the baltic sea. Environ. Sci. Technol. 45, 2011.

11. HELCOM BSEP No. 100, Nutrient Pollution to the Baltic Sea in 2000, 2000. 
12. HELCOM BSEP No. 115B, Eutrophication in the Baltic Sea An integrated thematic assessment of the effects of nutrient enrichment in the Baltic Sea region, 2007.

13. SZEFER P., FRELEK K., SZEFER K., LEE C., KIM B. S., WARZOCHA J., ZDROJEWSKA I., CIESIELSKI T. Distribution and relationships of trace metals in soft tissue, byssus and shells of Mytilus edulis trossulus from the southern Baltic. Environ. Pollut. 120, 423, 2002.

14. CONAN C., BOURAOUI F., TURPIN N., de MARSILY G., BIDOGLIO G. Modeling flow and nitrate fate at catchment scale in Brittany (France). J. Environ. Qual. 32, 2026, 2003.

15. SINGH V.P., FREVERT D.K. Watershed Models. CPR Press Taylor \& Francis Group, Boca Raton USA, 678, 2005.

16. OZGA-ZIELIFSKA, M., BRZEZIFSKI J. Applied Hydrology, $2^{\text {nd }}$ ed.; Polish Scientific Publishers, Warsaw, 1997 [In Polish].

17. JOHNSON B.E., JULIEN P.Y. The two-dimensional upland erosion model CASC2D-SED. In The Hydrology-Geomorphology Interface: Rainfall, Floods, Sedimentation, Land use, IAHS Proceedings \& Reports, Jerusalem, 261, 107, 2000.

18. JULIEN P.Y., SAGHAFIAN B., OGDEN F.L. RasterBased Hydrologic Modeling of Spatially-Varied Surface Runoff. J. Amer. Water Res. Assoc. 31 (3), 523, 1995.

19. ROJAS R., JULIEN P., JOHNSON B. CASC2D-SED v 1.0 - A 2-Dimensional Rainfall-Runoff and Sediment Model, Colorado State University, Colorado, 146, 2003.

20. SINGH V.P., FREVERT D.K. Mathematical models of small watershed hydrology and applications. Water Resources Publication LLC, USA, 972, 2002.

21. ADU J.T, KUMARASAMY M.V. Assessing Non-Point Source Pollution Models a Review. Pol. J. Environ. Stud. 27 (5), 1913, 2018.

22. GUSTAFSSON B. G. A time-dependent coupled-basin model of the Baltic Sea. C47, Earth Sciences Centre, Göteborg University, Göteborg, pp.61, 2003.

23. SAVCHUK O.P. Nutrient biogeochemical cycles in the Gulf of Riga: scaling up field studies with a mathematical model. J. Mar. Sys. 32, 253, 2002.

24. NEUMANN T., FENNEL W., KREMP Ch. Experimental Simulations with an Ecosystem Model of the Baltic Sea: A Nutrient Load Reduction Experiment. Glob. Biogeochem. Cycles 16 (3), 7, 2002.

25. EILOLA K., MEIER H.E.M., ALMROTH E. On the dynamics of oxygen, phosphorus and cyanobacteria in the Baltic Sea, A model study. J. Mar. Sys. 75, 163, 2009.

26. MEIER H.E.M., KAUKER F. Modeling decadal variability of the Baltic Sea: 2. Role of freshwater inflow and largescale atmospheric circulation for salinity. J. Geophys. Res. 108 (C11), 3368, 2003.

27. DZIERZBICKA-GŁOWACKA L., JAKACKI J.. JANECKI M., NOWICKI A. Activation of the operational ecohydrodynamic model (3D CEMBS) - the hydrodynamic part. Oceanologia 55 (3), 519, 2013a.

28. DZIERZBICKA-GŁOWACKA L., JANECKI M. NOWICKI A., JAKACKI J. Activation of the operational ecohydrodynamic model (3D CEMBS) - the ecosystem module. Oceanologia 55 (3), 543, 2013 b.

29. KORZENIEWSKI K. Klimat Zatoki i jej zlewiska: Zatoka Pucka. Fund. Roz. Univ. Gda., Gdańsk, Poland, 1993.

30. WĘSŁAWSKI J.M., KRYLA-STRASZEWSKA L., PIWOWARCZYK J., URBANSKI J., WARZOCHA J., KOTWICKI L., WŁODARSKA-KOWALCZUK M., WIKTOR J. Habitat model ling limitations - Puck Bay Baltic Sea-a case study. Oceanologia 55 (1), 167, 2013.

31. NEITSCH S.L., ARNOLD J.G, KINIRY J.R., WILLIAMS J.R. Soil and Water Assessment Tool: Theoretical documentation. Version 2005. Temple, Texas.: USDA-ARS Grassland. Soil Water Res. Lab. 2005.

32. BRZOZOWSKI J., MIATKOWSKI Z., ŚLIWINSKI D., SMARZYNSKA K., ŚMIETANKA M. Application of SWAT model to small agricultural catchment in Poland. J. Water Land Dev. 15, 157, 2011.

33. GASSMAN P.W., SADEGHI A.M., SRINIVASAN R. Applications of the SWAT Model Special Section: Overview and Insights. J. Environ. Qual. 43 (1), 1, 2014.

34. BRESSIANI D. DE A., GASSMAN P.W., FERNANDES J.G., GARBOSSA L.H.P., SRINIVASAN R., BONUMÁ N.B., MENDIONDO E.M. A review of soil and water assessment tool (SWAT) applications in Brazil: Challenges and prospects. Inter. J. Agricul. Biolog. Eng. 8, 1, 2015.

35. TAYLOR S.D., HE Y., HISCOCK K.M. Modelling the impacts of agricultural management practices on river water quality in Eastern England. J. Environ. Manage. 80, 147, 2016.

36. ZIMA P. Numerical Simulations and Tracer Studies as a Tool to Support Water Circulation Modeling in Breeding Reservoirs. Arch. Hydro-Eng. Environ. Mech. 61 (3-4), 217, 2014

37. JAWORSKA-SZULC B. Groundwater flow modelling of multi-aquifer systems for regional resources evaluation: The Gdansk hydrogeological system, Poland. Hydrogeol. J. 17, 1521, 2009

38. NOWICKI A., RAK D., JANECKI M., DZIERZBICKAGŁOWACKA L. Accuracy assessment of temperature and salinity computed by the 3D Coupled Ecosystem Model of the Baltic Sea (3D CEMBS) in the Southern Baltic. J. Oper. Oceanog. 9 (1), 67, 2016.

39. NOWICKI A., DZIERZBICKA-GŁOWACKA L., JANECKI M., KAŁAS M. Assimilation of satellite SST data in the 3D CEMBS model. Oceanologia 57 (1), 17, 2015.

40. PIETRZAK S. Sporządzanie bilansów składników nawozowych metoda „u bramy gospodarstwa”. Inst. Technol. Life Sci., Falenty, Poland. 2013 [in Polish].

41. KANA T.M., DARKANGELO O., HUNT M.D., OLDHAM B., BENNET G..E, CORNWELL J.C. A membrane inlet mass spectrometer for rapid high precision determination of $\mathrm{N}_{2}, \mathrm{O}_{2}$, and $\mathrm{Ar}$ in environmental water samples. Anal. Chem., 66, 4166, 1994.

42. ŚMIETANKA M. The influence of permanent grasslands on nitrate nitrogen loads in modelling approach. J. Water Land Dev. 21, 63, 2014. 